Reviews

\title{
Global Governance: Drawing Insights from the Environmental Experience. Oran R. Young, editor. Cambridge: The MIT Press (1998).
}

\author{
Reviewed by John H. Bodley, Department of Anthropology, Washington \\ State University
}

Everyone recognizes that since the breakup of the Soviet Union and the end of the Cold War in 1991, a truly global-scale capitalist economic system has become the primary determinant of how global resources are developed and how material benefits are distributed. Now the central question is - what is the nature of this global-scale, commercially-focused cultural system? How is it actually organized and directed, and toward what ends? Many assume that the global, "freemarket" economy is a self-organizing system, presumably guided by Adam Smith's "invisible hand" in a way that will ultimately benefit everyone in global society. Nevertheless, it is also clear that the global economy is in fact organized and directed by formal institutional structures, and it changes in response to pressures from specific interest groups that necessarily do not reflect everyone's interests. This book deals with these issues, but the conceptual framework employed leaves some really crucial realities in the background.

This book contains a collection of papers from the 1995 Dartmouth Conference on Governance in the Twenty-First Century. The book's rather modest title scarcely conceals the fact that the subject matter is what institutions, or who, is running the world. The book focuses on cultural responses to extremely important worldwide issues related to natural resources and the environment such as deforestation, biodiversity, river systems, fisheries, erosion, pollution, ozone depletion, and climate change. Throughout, a specialized vocabulary of deceptively subtle, and sometimes imprecisely defined political science concepts are employed to discuss a variety of institutional and organizational approaches to these global problems. New terms and acronyms are introduced, and sometimes familiar terms are used in unfamiliar ways. It is obvious that theorists are groping to understand a rapidly changing and very uncertain world in which the old frameworks no longer seem to apply.

The first three chapters offer a highly abstract discussion of the underlying conceptual issues, and deserve a very careful reading. The complexity of this discussion can be illustrated by the distinction drawn throughout between international and transnational. The distinction here is more than the not so apparent difference between among and across; it has to do with different types of social organizations with profound implications for the human future. In most of the examples discussed, governments, or governmental agencies are in fact the key actors in what is commonly recognized to be international society. This includes the world of international politics, diplomacy, treaty-making, legal conventions, and the United Nations, but extends beyond this familiar ground to include less prominent governmental activities.

Management action taking place among these nation state actors is appropriately referred to as international, whereas the very new concept of transnational refers to non-governmental organizations operating as members of a presumably emerging global (transnational) civil society, rather than the international political society. This distinction may seem trivial, but it is crucial if 


\section{Reviews}

we are to understand a world that is becoming increasingly dominated by the "New Growth Theory" of laissez-faire capitalism, which advocates aggressive reductions in the role of governments as regulators of global commerce, the removal of all trade barriers, and management of the global system by negotiations among private, self-selected interest groups, often with very unequal relative levels of power.

Global governance is the cover concept that refers to the managerial activities performed by any and all of the relatively new social institutions such as the United Nations, various regional, sometimes quasi-governmental, commissions, and Non-governmental organizations that have emerged primarily since World War II to deal with diverse world problems. When concerned with environmental issues, governance refers to institutionalized, internationally agreed-upon guidelines, rules, and procedures for the management of common property resources including rivers, ecosystems, and the global climate. The authors of these papers emphasize that governance does not require government, and draw a very important distinction between governments and regimes, both of which are distinct institutional forms that now play a role in global governance. Government refers to centralized, hierarchical bureaucracies, with large staffs, big budgets, and permanent structures, and that exercise sovereign rights. The authors assume that as so defined, there is no global government, and it is unlikely to ever arise, but instead a multitude of regimes have emerged to solve collective problems in international society and world civil society. This use of the term "regime" at first seems confusing, because it commonly connotes government, but a regime can be any managing set of rules. Regimes are loosely defined as issue-specific social institutions that design and administer rules, procedures, and programs, and whose official members so far are usually, but not necessarily, states. The concept of regime is so broad that it can even be applied to the organization of a clan system in small-scale, domestically-organized societies. At the other extreme, the United Nations system is presumably too large and diverse to be considered a regime in the specific sense used here, and although it is primarily an intergovernment organization, it is not itself a politically sovereign government. In the context of global-scale governance, regimes are relatively decentralized worldwide organizations that include the General Agreement on Tariffs and Trade (GATT), the World Trade Organization (WTO), the Antarctic Treaty System, and many international river basin commissions, as well as such prominent organizations as the World Bank and the International Monetary Fund.

The middle chapters survey examples of specific organizations and present limited case studies, whereas the final section is devoted to broader issues and institutional "linkages" between institutions, and between economic and environmental issues. The discussion of the World Bank in Chapter 8 is especially useful. This broad mix of material gives a good feel for what global regimes are about. However, curiously absent throughout this discussion is any focused consideration of social power in the treatment of the creation and modification of international regimes. This omission is intentional, because although editor Oran Young expresses an interest in "driving forces," he declares that "a preoccupation with power . . . is misplaced in the study of international and transnational regimes" (p. 18). This strikes me as a misguided, especially given that the papers in this collection are almost totally silent on the subject of multinational corporations as obviously powerful actors shaping environmentally-related global regimes. Multinationals are only specifically mentioned by one author. There is also no mention of the possible existence of a global policy-shaping network composed of the diverse philanthropic foundations that fund conferences and research on global issues, and the prestigious private, invitation-only membership organizations such as the Council on Foreign Relations in the United States, and the Trilateral Commission for Western Europe, Japan, and the United States, that actively seek to define the legitimate boundaries of discussions about global governance. Despite their self-identity as "concerned citizens," the members of these influential policy-formulating bodies are not broadly representative members of global civil society. Perhaps even more importantly, the concept of civil society as used in the book makes no distinction between commercial and noncommercial organizations within civil society. This means that enormously powerful for-profit business corporations are deceptively treated as just another "citizen" in global 
Reviews

society, because they are not governments, yet their economic power is as great or greater than many national governments. For example, General Motors' 1997 revenues exceeded the gross domestic products of all but the very largest countries. In 1997, the combined revenues of the 25 largest U.S. corporations equaled the revenue of the U.S. federal government. It is significant that Mobil Oil, the eight largest U.S. corporation with 1997 revenues of $\$ 60$ billion, ran a vigorous ad campaign in the business press against the global warming treaty. The power of financial capital cannot be ignored. In the capitalist system, the world's largest investors, whether operating as institutions or private individuals, will be likely to have the loudest voice and greatest influence on any regimes that will be concerned with natural resources. However, commercial interests may have a very low public profile.

There is also little attempt in this book to analyze why global governance is needed in the first place. This is a serious omission, because it obscures the reality that the very agencies (giant multinational corporations) that have created the "current challenges of governance," through their pursuit of unlimited economic growth, are the very agencies that are becoming the most active global civic society shapers of the new governing regimes. We might suspect that their participation might be self-serving, and their particular vision is likely to be short-sighted, given that investor response to quarterly profit returns are now the primary determinants of corporate policy. However, what I perceive as shortcomings in this book in no way detract from its overall importance. This collection is an excellent general introduction to the language and conceptual frameworks, as currently presented in the literature on global regimes. These are extremely timely issues that deserve a much wider audience.

\section{The Gendered Terrain of Disaster: Through Women 's Eyes, Edited by Elaine Enarson and Betty Hen Morrow, Westport CT: Praeger Press, 1998 xiii, 275 pp.}

\section{Reviewed by Pamela S. Showalter, Department of Geography and Planning, Southwest Texas State University, San Marcos, TX 78666.}

The editors of The Gendered Terrain of Disaster: Through Women Eyes have several ambitious goals. They attempt to address the disaster literature's general paucity of information regarding the gendered terrain within which disasters are experienced, offer workable recommendations to planners and practitioners for incorporating women and gender issues into their work, provide researchers with new directions for conducting studies and for utilizing and constructing theory, as well as provide the general reader with "... a new perspective on women's experiences, needs, and interests in disasters" (p. xii). No matter your area of expertise, if you are engaged in efforts to reduce the impact of disasters on humanity, this is an instructive volume regardless of whether or not you have an interest in "gender issues" per se.

Following introductory remarks, the book is separated into three sections, beginning with an overview of the topic to reveal theoretical gaps and directions as well as field-based themes. The second section addresses the social construction of vulnerability vis-à-vis issues of age and poverty, land ownership and family structure, domestic violence and community organization, and how vulnerability is rooted in gender and national development. The third section provides a 